\title{
Sejarah Pengecualian Rahasia Bank Dalam Upaya Pemberantasan Tindak Pidana Korupsi Di Indonesia
}

\author{
Fabriant \\ Fakultas Hukum Universitas Indonesia \\ Email :Fabriant00@gmail.com
}

\begin{abstract}
Bank secrecy is the main principle in the banking business, and one of the elements that can increase public trust is that banks can trust the bank to keep information about their depositing customers secret. There are 2 theories regarding bank secrecy, namely absolute bank secret theory and relative bank secret theory. In Indonesia, bank secrets can be excluded for several purposes, one of which is for the purpose of eradicating corruption. Currently the regulation regarding bank secrecy exeptions, have been stated in act No. 7/1992 concerning Banking as Amended by Act No. 10/1998. These regulations do not just appear, there is a lengthy process and reforms undertaken regarding bank secrecy arrangements in Indonesia. The history of bank secret exceptions in Indonesia is divided into 3 time periods, namely: The period of the old order government, the period of the new order government, and the period of the reformation government. It can be concluded from the three periods that the regulation of bank secret exeptions in an effort to eradicate corruption in Indonesia has been renewed several times, This is done due to increasingly sophisticated crimes so that a regulation regarding the exception of bank secrets is needed which can facilitate law enforcement officers in carrying out their duties.
\end{abstract}

Key Words: Bank Secrecy Exeptions, History, Corruption.

Abstrak. Rahasia bank merupakan prinsip utama dalam bisnis perbankan, dan salah satu unsur yang dapat meningkatkan kepercayaan masyarakat yaitu dapat dipercayakah bank untuk merahasiakan informasi mengenai nasabah penyimpannya, Terdapat 2 Teori mengenai kerahasiaan bank yaitu teori rahasia bank mutlak (ablosut) dan teori rahasia bank nisbi (relatif). di Indonesia rahasia bank dapat dikecualikan untuk beberapa kepentingan, salah satunya untuk kepentingan pemberantasan korupsi. Saat ini pengaturan mengenai pengecualian rahasia bank tercantum dalam Undang-undang Nomor 10 Tahun 1998 tentang Perubahan Atas Undang-Undang Nomor 7 Tahun 1992 Tentang Perbankan. Peraturan tersebut tidak serta muncul begitu saja, terdapat proses yang panjang dan pembaharuan yang dilakukan terhadap pengaturan rahasia bank di Indonesia. Sejarah pengecualian rahasia bank di Indonesia dibagi menjadi 3 periode waktu yaitu: Periode masa pemerintahan orde lama, Periode masa pemerintahan orde baru, dan Periode masa pemerintahan reformasi. Dapat diambil kesimpulan dari ketiga periode tersebut bahwa pengaturan pengecualian rahasia bank dalam upaya memberantas korupsi di Indonesia beberapa kali dilakukan pembaharuan, hal ini dilakukan dikarenakan kejahatan yang semakin canggih sehingga diperlukan suatu aturan mengenai pengecualian rahasia bank yang dapat memudahkan aparat penegak hukum dalam menjalankan tugasnya.

Kata Kunci : Pengecualian Rahasia Bank, Sejarah, Korupsi.

\section{PENDAHULUAN}

Mewujudkan masyarakat yang adil dan makmur berdasarkan Pancasila dan UndangUndang Dasar 1945 merupakan tujuan pembangunan nasional, perbankan mempunyai peranan yang sangat penting. Peran lembaga keuangan khususnya perbankan, sangat signifikan bagi pergerakan roda perekonomian nasional. Definisi bank menurut Prof. G.M. Verryn Stuart, yaitu suatu badan yang bertujuan untuk memuaskan kebutuhan kredit, baik dengan alat-alat pembayarannya sendiri atau dengan uang yang diperolehnya dari orang lain, maupun dengan 
jalan memperedarkan alat-alat penukar baru berupa uang giral.

Bank dalam menjalankan bisnisnya dilandasi oleh empat prinsip penting yaitu prinsip kepercayaan (fiduciary principle), prinsip kehati-hatian (prudential principle), prinsip kerahasiaan (confidential principle), dan prinsip mengenal nasabah (know your customer principle). Menurut Sutan Remy Sjahdeini Bank adalah suatu lembaga keuangan yang eksistensinya tergantung mutlak pada kepercayaan dari para nasabah yang mempercayakan dana dan jasa-jasa lain yang dilakukan mereka melalui bank pada khususnya dan dari masyarakat luas pada umumnya. Oleh karena itu, sangat penting bagi bank untuk menjaga kadar kepercayaan masyarakat yang telah menyimpan dananya, masyarakat yang akan menyimpan dananya, maupun yang telah atau akan menggunakan jasa-jasa bank lainnya, terpelihara dengan baik dalam tingkat yang tinggi. Lebih lanjut Sutan Remi menegaskan Kepercayaan masyarakat kepada bank merupakan unsur pokok dari eksistensi suatu bank.

Salah satu unsur yang paling pokok untuk meningkatkan kepercayaan masyarakat kadar kepercayaan masyarakat kepada bank adalah dapat tidaknya bank dipercaya nasabah yang menyimpan dana dan/atau menggunakan jasa-jasa lainnya dari bank tersebut untuk tidak mengungkapkan keadaan keuangan dan transaksi nasabah, serta keadaan lain dari nasabah yang bersangkutan kepada pihak lain. Dapat disimpulkan prinsip kepercayaan masyarakat merupakan prinsip utama dalam bisnis perbankan, dan salah satu unsur yang dapat meningkatkan kepercayaan masyarakat yaitu dapat dipercayakah bank untuk merahasiakan informasi mengenai nasabah penyimpannya (rahasia bank).

Penerapan kerahasiaan bank sama tuanya dengan perkembangan perbankan sendiri. Bahkan sudah ada sejak 4000 tahun yang lalu di Babylonia sebagaimana tercantum dalam Code of Hamourabi. Aturan kerahasiaan bank yang dalam perkembangannya juga diakui sebagai bagian dari hak asasi manusia yang berfungsi untuk melindungi rahasia pribadi orang tersebut (right of privacy) serta keuangannya (financial privacy).

Tonggak sejarah rahasia bank adalah kasus Tournier vs National Provincial and Unio Bank of England (1924), namun sebenarnya awal sejarah rahasia bank berawal dari sejarah kerahasiaan itu sendiri. Terdapat kasus yang terkenal terkait kerahasiaan yakni Prince Albert vs strange (1848) terkait publikasi katalog lukisan pribadi yang dibuat oleh Ratu Victoria dan Pangeran Albert. Kasus ini walau bukan merupakan kasus rahasia bank namun merupakan tonggak sejarah awal kerahasiaan dipertahankan di depan hukum.

Terdapat 2 Teori mengenai kerahasiaan bank yaitu teori rahasia bank mutlak (ablosut) dan teori rahasia bank nisbi (relatif). Teori rahasia bank bersifat mutlak berarti bank wajib menyimpan rahasia bank yang diketahui oleh bank karena kegiatan usahanya dalam keadaan apapun, biasa atau dalam keadaan luar biasa. Teori rahasia bank bersifat nisbi berarti bank diperbolehkan membuka rahasia bank dalam keadaan mendesak, misalnya demi kepentinga negara atau demi kepentingan peradilan pidana.

Masalah korupsi sangat serius di berbagai negara tak terkecuali di Indonesia, dan telah mengancam stabilitas dan keamanan masyarakat nasional dan internasional, Salah satu kendala dalam pemberantasan korupsi adalah modus operandi yang semakin canggih dengan menggunakan bank sebagai tempat penyimpanan hasil kejahatan. Berkaitan dengan masalah tersebut, untuk memberantas korupsi di Indonesia, rahasia bank dapat dikecualikan untuk kepentingan peradilan pidana. Indonesia menganut teori rahasia bank bersifat relatif dikarenakan di Indonesia diperbolehkan untuk membuka/mengecualikan rahasia bank untuk beberapa kepentingan, salah satunya untuk kepentingan peradilan pidana dan juga dalam upaya pemberantasan tindak pidana korupsi.

Berdasarkan hal tersebut penulis memiliki ketertarikan untuk membahas mengenai "Sejarah pengecualian rahasia bank dalam upaya pemberantasan tindak pidana korupsi di Indonesia". Penulis akan membatasi pembahasan hanya terbatas pada pembahasan pengecualian rahasia bank dalam upaya 
pemberantasan tindak pidana korupsi di Indonesia dengan membagi menjadi 3 (tiga) rentang waktu periode, yaitu : Pertama, Pengecualian rahasia bank pada masa pemerintahan orde lama; Kedua, Pengecualian rahasia bank pada masa pemerintahan orde baru; dan ketiga, Pengecualian rahasia bank pada masa pemerintahan pasca reformasi.

\section{PEMBAHASAN}

\section{A. Sejarah Pengecualian Rahasia Bank Dalam Upaya Pemberantasan Tindak Pidana Korupsi di Indonesia Pada Masa Pemerintahan Orde Lama}

\section{Awal Mula Pengaturan Rahasia Bank}

Setelah Indonesia memproklamirkan kemerdekaan, pajak menjadi salah satu opsi penting yang dibahas pemerintah Republik Indonesia, Selain masalah pajak, Inflasi dan korupsi juga menjadi masalah utama dalam kepemimpinan soekarno. Puncaknya adalah ketika di tahun 1960an rezim Orde Lama sedang gencar-gencarnya melaksanakan kampanye "Ganyang Malaysia" dan menggalakan proyek-proyek mercusuar seperti pembangunan Senayan dan Monumen Nasional. Akibatnya adalah inflasi yang meroket pada saat itu mencapai $500 \%$.

Permasalahan tersebut menyebabkan penarikan dana nasabah secara besar-besaran (rush), sehingga diperlukan peraturan yang suatu peraturan yang dapat menstabilkan kondisi perekonomian saat itu. Kemudian pemerintah mensahkan Peraturan Pemerintah Pengganti Undang-Undang Nomor 23 Tahun 1960 Tentang Rahasia bank. Disahkannya PERPU ini, sebagai upaya pemerintah memberikan kepastian hukum bagi masyarakat dalam menjamin kerahasiaan atas simpanan dan berbagai jenis hubungan transaksi mereka dengan bank. Hal itu ditempuh untuk mengantisipasi kurangnya minat masyarakat untuk menyimpan dananya kepada perbankan.Di sisi lain untuk membantu aparat penegak hukum dalam mengungkap suatu perkara pidana, PERPU No. 23 Tahun1960 memberikan pengecualian bahwa rahasia bank dapat dikecualikan untuk kepentingan perkara pidana.
Pasal 3 ayat 2 PERPU No. 23 Tahun 1960 menyatakan bahwa untuk kepentingan peradilan pidana Menteri Pertama dapat memberi izin kepada Jaksa/Hakim untuk meminta pada Bank keterangan tentang keadaan keuangan tersangka/terdakwa. Lebih lanjut Izin tersebut diberikan secara tertulis atas permintaan Jaksa Agung apabila yang memerlukan keterangan adalah Jaksa dan atas permintaan Ketua Mahkamah Agung apabila Hakim yang memerlukan keteranganketerangan itu. Berdasarkan ketentuan tersebut, rahasia bank dapat dikecualikan dalam perkara pidana dengan terlebih dahulu meminta izin kepada menteri pertama.

2. Undang-Undang Pidana Diluar KUHP Pertama Yang Memuat Ketentuan Pengecualian Rahasia Bank

Selain mensahkan Peraturan Pemerintah Pengganti Undang-Undang Nomor 23 Tahun 1960 Tentang Rahasia bank. Pada tahun 1960, Dalam keadaan mendesak salah satu upaya yang dilakukan pemerintah untuk menekan tindak pidana korupsi dengan mengeluarkan Peraturan Pemerintah Pengganti Undang-Undang Nomor 24 Tahun 1960 Tentang Pengusutan, Penuntutan, dan Pemeriksaan Tindak Pidana Korupsi. PERPU ini merupakan upaya penyempurnaan atas Peraturan Penguasa Perang Pusat Nomor PRT/PEPERU/013/1958. Penyempurnaan dilakukan dengan memasukan ketentuan pengecualian rahaia bank dalam rumusannya Peraturan ini merupakan undang-undang pidana diluar KUHP pertama yang memuat ketentuan pengecualian rahasia bank.

PERPU No. 24 Tahun 1960 memuat ketentuan pengecualian rahasia bank yang dirmuskan pada pasal 5 ayat 4 yang menyatakan bahwa bank hanya memberi keterangan tentang keadaan keuangan tersangka yang diminta oleh Jaksa apabila permintaan itu dilakukan menurut cara-cara yang ditentukan dalam Peraturan tentang rahasia Bank. Hal ini dilakukan untuk memperlancar proses penyidikan, penuntutan dan pemeriksaan tindak pidana korupsi. Namun untuk mekanisme pelaksanaan pengecualiannnya tetap mengacu pada 
ketentuan yang ada pada PERPU No. 23 tahun 1960 Tentang Rahasia bank.

\section{B. Sejarah Pengecualian Rahasia Bank Dalam Upaya Pemberantasan Tindak Pidana Korupsi di Indonesia Pada Masa Pemerintahan Orde Baru.}

1. Pengaturan rahasia bank dimasukan kedalam Undang-Undang Perbankan

Tahun 1965 merupakan tahun yang bersejarah bagi bangsa Indonesia, penderitaan rakyat semakin meningkat akibat dari kemerosotan ekonomi Indonesia yang disebabkan oleh missmanagement, pemborosan, birokrasi, korupsi, dsb. Ditambah lagi pada tahun ini terjadi gerakan kontra revolusi G.30.S/PKI dan penyelewenganpenyelewengan terhadap UUD 1945. pengkhianatan G-30-S/PKI digunakan dalam segala bentuk dan cara untuk melakukan gerakan dan tipu daya yang jahat yang hampirhampir dapat mengelabui rakyat untuk membelokkan jalanya keluar dari dasar Pancasila. Oleh sebab itu perlu dilakukan pembaharuan kebijakan dibidang ekonomi, keuangan dan pembangunan. Untuk mengantisipasi hal tersebut Majelis Permusyawaratan Rakyat Sementara menetapkan TAP MPRS No. XXIII/MPRS/1966 tentang pembaharuan kebijakan landasan ekonomi, keuangan, dan pembangunan. Pasal 55 ketetapan tersebut mengamanatkan untuk harus segera menetapkan Undang-undang Pokok Perbankan dan Undang-undang Sentral.

Untuk merespon ketetapan tersebut pemerintah Indonesia segera merumuskan Undang-Undang Nomor 14 Tahun 1967 Tentang Pokok-Pokok Perbankan. Pemberlakuan sekaligus mencabut PERPU Nomor 23 Tahun 1960 tentang Rahasia Bank dikarenakan didalam UU No. 14 Tahun 1967 sudah mengadopsi ketentuan mengenai rahasia bank. Apabila dicermati tidak ada perubahan signifikan antara pengaturan rahasia bank dalam PERPU No. 23 Tahun 1960 tentang Rahasia Bank dengan pengaturan dalam UU No. 14 Tahun 1967 tentang Pokok-Pokok Perbankan. Rumusan pengecualian rahasia bank dalam UU No. 14
Tahun 1967 sama dengan PERPU No. 23 Tahun 1960 yaitu hanya dikecualikan dalam perkara perpajakan dan perkara pidana. Dalam perkembangannya pemerintah mencabut UU No. 14 Tahun 1967 tentang pokok-pokok perbankan dan mensahkan Undang-Undang Nomor 7 Tahun 1992 Tentang Perbankan.

\section{Penambahan Ketentuan Jangka Waktu}

Selanjutnya pada tahun 1970an di Indonesia, Penegakan hukum atas tindak pidana korupsi masih sangat lemah, selain tidak jelasnya kemauan politik pemerintah (political will), PERPU No. 24 Tahun 1960 Tentang Pengusutan, Penuntutan, dan Pemeriksaan Tindak Pidana Korupsi dianggap tidak marnpu menjangkau makin meluasnya tindak pidana Korupsi. Akhirnya berdasarkan tekanan publik pada waktu itu , PERPU No. 24 Tahun 1960 diperbaharui dengan UndangUndang Nomor 3 Tahun 1971 tentang pemberantasan tindak pidana korupsi yang menjadi generasi keempat undang-undang pengakkan tindak pidana korupsi.

Pada UU No. 3 tahun 1971 tentang pemberantasan tindak pidana korupsi terdapat penambahan pengaturan mengenai jangka waktu pemberian keterangan oleh bank. Pasal 9 pada ayat 3 bahwa bank harus memberikan keterangan yang diminta dalam jangka waktu 14 (empat belas) hari sejak tanggal penerimaan permintaan ijin itu oleh Menteri Keuangan. Hal ini berarti setelah semua mekanisme pembukaan rahasia bank terpenuhi, bank wajib memberikan keterangan yang diminta sesuai dengan jangka waktu yang telah ditetapkan, yaitu 14 hari.

C. Sejarah Pengecualian Rahasia Bank Dalam Upaya Pemberantasan Tindak Pidana Korupsi di Indonesia Pada Masa Pemerintahan Pasca Reformasi

1. Pembatasan Lingkup Rahasia Bank Masyarakat merasa tidak puas atas rumusan rahasia bank sebagaimana dirumuskan dalam Undang-Undang Nomor 7 Tahun 1992 Tentang Perbankan, di mana rumusan itu terlalu jauh karena sampai mencakup kredit bank yang diberikan kepada nasabah. Masyarakat berpendapat bahwa seyogyanya lingkup rahasia bank hanya 
meliputi dana simpanan nasabah saja (pasiva bank) dan keterangan yang menyangkut penyimpanan nya. Lingkup rahasia bank yang meliputi kredit yang diterima oleh nasabah (aktiva bank), dirasakan oleh masyarakat sebagai pemasungan hak masyarakat untuk mengetahui kredit-kredit macet perbankan yang sangat mempengaruhi kesehatan perbankan.

Sehubungan dengan itu, rumusan dan ruang lingkup kerahasiaan bank telah diubah dengan Undang-Undang Nomor 10 Tahun 1998, yang dirumuskan terdapat dalam ketentuan Pasal 1 angka 28 Undang-Undang Nomor 7 Tahun 1992 sebagaimana telah diubah dengan Undang-Undang Nomor 10 Tahun 1998, yaitu "Rahasia bank adalah segala sesuatu yang berhubungan dengan keterangan mengenai nasabah penyimpan dan simpanannya". Dengan demikian UndangUndang Nomor 7 Tahun 1992 sebagaimana telah diubah dengan Undang-Undang Nomor 10 Tahun 1998 telah membatasi atau mempersempit ruang lingkup rahasia bank hanya berhubungan dengan nasabah penyimpan dana (nasabah kreditor) dan simpanannya dan selebihnya yang berhubungan dengan nasabah peminjam dana (nasabah debitur) dan kredit tidak termasuk yang wajib dirahasiakan oleh bank.

Berkaitan dengan pengecualian rahsia bank, UU No. 10 Tahun 1998 melakukan pelimpahan pemberian izin untuk membuka rahasia, yang sebelumnya izin dimohonkan kepada menteri keuangan. Namun saat dengan berlakunya undang-undang ini, pemberian izin dilakukan oleh pimpinan Bank Indonesia. Kemudian dalam perkembangannya kewenangan pimpinan Bank Indonesia diambil alih oleh otoritas jasa keuangan (OJK), dalam UU No. 21 tahun 2011 tentang otoritas jasa keuangan. Pasal 69 ayat (1) huruf $b$ dan huruf c, yang pada intinya mengatur bahwa kewenangan Bank Indonesia dalam pasal 41, Pasal 41A, Pasal 42 dan Pasal 43 UU Perbankan untuk memberikan izin kepada pihak terkait untuk membuka rahasia bank diambil alih oleh OJK.

\section{Penambahan} Pemblokiran Rekening
Pada awal pemerintahan pasca reformasi, tepatnya pada tanggal 1 april 1999 harian kompas membuat berita "INDONESIA, NEGARA PALING KORUP DI ASIA" dalam berita tersebut dijelaskan bahwa indonesia merupakan negara dengan tingkat korupsi paling tinggi di Asia. Hal ini berarti semenjak diberlakukannya UU No. 3 Tahun 1971 tentang pemberantasan tindak pidana korupsi selama 28 Tahun, tidak dapat menanggulangi permasalahan korupsi di Indonesia.

Karena hal itu UU No. 3 Tahun 1971 kembali diperbarui dan disesuaikan dengan kebutuhan hukum dan aspirasi masyarakat yang berkembang dan digantikan dengan Undang-Undang Nomor 31 Tahun 1999 Tentang Pemberantasan Tindak Pidana Korupsi. Menurut Prof. DR. Muladi, SH ada 6 aspek yang menarik atas revisi terhadap UU No. 3 Tahun 1971 yang salah aspeknya yaitu untuk memperlancar proses penyidikan, penuntutan dan pemeriksaan tindak pidana korupsi, Polisi, Jaksa atau Hakim sesuai dengan tingkat penanganan perkara dapat langsung meminta keterangan tentang keadaan tersangka atau terdakwa kepada bank melalui Gubernur Bank Indonesia.

Hal yang menarik lainnya pada UU No. 31 Tahun 1999 yaitu Penyidik, Penuntut Umum dan Hakim dapat mengajukan permohonan kepada Gubernur Bank Indonesia untuk mengetahui keadaan keuangan sekaligus memblokir Rekening Simpanan Terdakwa. Selambat-lambatnya 3 hari setelah dokumen perminintaan diterima secara lengkap. Pemblokiran rekening diperlukan untuk menangani kasus-kasus khusus dan mutakhir yang sulit pembuktiannya. Dalam hal ini disadari bahwa kasus korupsi sulit dalam pembuktiannya, seringkali permasalahan yang timbul yaitu pada saat kasus terungkap uang hasil korupsi sudah dipindahkan ketempat lain. Maka dari itu diperlukan diperlukan suatu aturan yang dapat mengantisipasi hal tersebut. Ketentuan ini terdapat dalam pasal 29 ayat 4 UU No. 31 Tahun 1999 yang menyatakan "Penyidik, penuntut umum, atau hakim dapat meminta kepada bank untuk memblokir rekening simpanan milik tersangka atau terdakwa yang diduga hasil dari korupsi." 
Namun, apabila tersangka atau terdakwa terbukti tidak melakukan tindak pidana maka pemblokiran dapat dicabut, ketentuan ini terdapat didalam pasal 29 ayat 5 UU No. 31 Tahun 1999 yang menyatakan "Dalam hal hasil pemeriksaan terhadap tersangka atau terdakwa tidak diperoleh bukti yang cukup, atas permintaan penyidik, penuntut umum atau hakim, bank pada hari itu juga mencabut pemblokiran".

\section{Fenomena Baru Pengecualian Rahasia Bank Dalam Upaya Pemberantasan Korupsi}

Tidak dapat dipungkiri bahwa tindak pidana korupsi pada hakekatnya sebagai kejahatan yang luar biasa (extraordinary crime). Oleh karena itu dalam penanganannya pun juga menggunakan cara-cara yang luar biasa. Berkaitan dengan hal tersebut, pada tahun 2002 Indonesia membentuk suatu lembaga super body yang bertugas memberantas korupsi yang dikenal dengan nama Komisi Pemberantasan Korupsi. Pembentukan KPK didasari oleh UU No. 30 Tahun 2002 tentang Komisi Pemberantasan Korupsi. Berdasarkan Undang-Undang tersebut, KPK memiliki tugas melakukan tugas kordinasi dengan instansi yang berwenang melakukan pemberantasan tindak pidana korupsi; supervisi terhadap instansi yang berwenang melakukan pemberantasan tindak pidana korupsi; penyelidikan, penyidikan dan penuntutan terhadap tindak pidana korupsi; melakukan tindakan-tindakan pencegahan tindak pidana korupsi; dan melakukan pemantauan (monitoring) penyelenggaraan pemerintahan negara.

Sementara itu kewenangan yang dimiliki oleh KPK adalah mengkoordinasikan penyelidikan, penyidikan, penuntutan terhadap tindak pidana korupsi; meletakkan sistem pelaporan dalam kegiatan pemberantasan tindak pidana korupsi; meminta informasi tentang kegiatan pemberantasan tindak pidana korupsi kepada instansi terkait;melaksanakan dengar pendapat atau pertemuan dengan instansi yang berwenang melakukan pemberantasan tindak pidana korupsi, meminta laporan instansi terkait mengenai pencegahan tindak pidana korupsi.
Pembentukan KPK merupakan fenomena baru dalam penegakan hukum dibidang korupsi di Indonesia. Dikarenakan KPK adalah lembaga pertama yang didalamnya terdiri atas jaksa dan polisi (satu atap). Lembaga ini dibentuk sebagai salah satu bagian agenda pemberantasan korupsi yang merupakan salah satu agenda terpenting dalam pembenahan tata pemerintahan di Indonesia.Kaitan antara komisi pemberantasan korupsi dan rahasia bank yaitu KPK dalam melaksanakan tugas penyidikan, penyelidikan dan penuntutan, tidak dibatasi oleh ketentuan rahasia bank, dasar hukumnya adalah pasal 12 huruf c UU No. 30 Tahun 2002 tentang Komisi Pemberantasan Tindak Pidana Korupsi. Pasal tersebut menyatakan bahwa KPK dalam melaksanakan tugas penyelidikan, penyidikan, dan penuntutan terhadap tindak pidana korupsi berwenang meminta keterangan kepada bank atau lembaga keuangan lainnya tentang keadaan uang tersangka atau terdakwa yang sedang diperiksa.

UU No. 30 Tahun 2002 tentang komisi pemberantasan korupsi mengenyampingkan UU No. 31 Tahun 1999 tentang Pemberantasan Tindak Pidana Korupsi sebagaimana telah diubah oleh UU No. 20 Tahun 2001 dan UU No. 7 Tahun 1992 tentang Perbankan sebagaimana telah diubah oleh UU No. 10 Tahun 1998, khusus pada bagian mengenai prosedur izin membuka rahasia bank. Hal itu dikuatkan oleh fatwa Mahkamah Agung seperti yang tertuang dalam surat bernomor KMA/694/RHS/XII/2004 yang ditandatangani oleh Ketua Mahkamah agung yang pada saat itu diketuai oleh Bagir Manan dan ditujukan kepada Gubernur Bank Indonesia. Surat ini menjawab surat BI tertanggal 8 Agustus 2004 lalu yang meminta agar lembaga keadilan tertinggi itu memberikan pertimbangan hukum atas pelaksanaan kewenangan KPK terkait dengan ketentuan rahasia bank.

Berdasarkan wewenang yang dimilikinya tersebut, KPK dalam melakukan penyidikan, penyelidikan dan penuntutan apabila membutuhkan data pribadi atau data transaksi yang dilakukan oleh nasabah suatu bank tidak perlu untuk meminta izin kepada Gubernur Bank Indonesia/Otoritas Jasa 
Keuangan (pemberian izin membuka rahasia bank sejak tahun 2011 dilimpahkan kepada Otoritas Jasa Keuangan). KPK dapat meminta langsung kepada bank yang bersangkutan terkait data yang dibutuhkan tersebut. Wewenang KPK yang menyampingkan mekanisme pembukaan Rahasia bank tersebut untuk mempercepat proses penyelidikan dan penyidikan. Ada pendapat atau persepsi bahwa ketentuan rahasia bank di Indonesia dengan pengecualian yang bersifat limitatif dan birokratis dapat dianggap sebagai penghambat proses penegakan hukum di Indonesia. Menyangkut hal ini Badan Pengawas Keuangan dan Pembangunan (BPKP) berpendapat bahwa Ketentuan rahasia bank merupakan penghambat di dalam pemberantasan suatu tindak pidana. Bahkan ada yang berpendapat bahwa ketentuan rahasia bank dapat dijadikan "tameng" untuk bersembunyi bagi pelaku tindak pidana.

Dalam perkembangannya, KPK tidak lepas dari isu politik hukum, beberapa perubahan dilakukan terhadap lembaga yang dianggap super body ini, perubahan yang dilakukan salah satunya yaitu dibentuknya dewan pengawas yang bertugas untuk mengawasi pelaksanaan tugas dan wewenang KPK. Dengan dibentuknya dewan pengawas, KPK dalam melaksanakan penyadapan harus meminta izin terlebih dahulu kepada dewan pengawas. Namun dalam menjalankan tugasnya yang berhubungan dengan pembukaan rahasia bank, KPK tetap diberikan kewenangan untuk meminta data transaksi langsung kepada bank tanpa meminta izin terlebih dahulu.

\section{KESIMPULAN}

Ketentuan mengenai rahasia bank dibuat untuk menjaga kadar kepercayaan masyarakat kepada bank untuk tetap menyimpan simpananya di bank. Namun dikarenakan teori yang dianut rahasia bank di Indonesia adalah teori relatif, artinya rahasia bank dapat dikecualikan untuk beberapa kepentingan, salah satunya untuk kepentingan memberantas korupsi dalam perkara pidana. Undang-undang pemberantasan tindak pidana korupsi mulai dari tahun 1960-sekarang semuanya memasukan rumusan pengecualian rahasia bank.
Awalnya pengecualian rahasia bank untuk kepentingan perkara pidana harus melalui mekanisme permintaan izin kepada pihak yang berwenang memberikan izin, wewenang pemberian izin awalnya diberikan oleh menteri keuangan, setelah diberlakukannya UU No. 10 Tahun 1998 Tentang Perbankan, wewenang tersebut dilimpahkan kepada Gubernur Bank Indonesia, kemudian dilimpahkan lagi kepada Otoritas Jasa Keuangan.

Namun ketentuan mekanisme pengecualian rahasia bank ini tidak berlaku bagi Komisi Pemberantasan Korupsi, Lembaga yang bertugas untuk memberantas korupsi ini mempunyai wewenang yang mengenyampingkan mekanisme pengecualian rahasia bank. Artinya, Komisi Pemberantasan Korupsi dapat meminta keterangan langsung kepada bank terkait simpananya tanpa memerlukan izin dari gubernur Bank Indonesia atau Otoritas Jasa Keuangan.

\section{DAFTAR PUSTAKA \\ Buku}

Garnasih, Yenti. Kriminalisasi Pencucian Uang. Jakarta : Pasca Sarjana Fakultas Hukum Universitas Indonesia, 2003.

Gazali, Djoni S dan Rachmadi Usman, Hukum Perbankan. Jakarta: Sinar Grafika, 2012.

Husein, Yunus. Rahasia Bank Dan Penegakan Hukum. Jakarta: Pustaka Juanda Tiga Lima, 2010.

Museum Bank Indonesia ,Unit Khusus. Sejarah Bank Indonesia: Perbankan. Jakarta: Unit Khusus Museum Bank Indonesia, 2007.

Pranacitra, Resi. Rahasia Bank: As A Tool Economic Engineering. Yogyakarta: Lautan Pustaka, 2019.

Suyatno, Thomas. et al., Kelembagaan Perbankan. Jakarta: Gramedia, 1992.

Artikel, Jurnal, dan Makalah. 
Badjuri, Achmad. "Peranankomisi Pemberantasan Korupsi (KPK) Sebagai Lembaga Anti Korupsi Di Indonesia," Bisnis dan Ekonomi 18 (2011). Hlm. 8496.

Fitria, "Eksistensi Komisi Pemberantasan Korupsi (KPK) Sebagai Lembaga Negara Penunjang Dalam Sistem Ketatanegaraan Indonesia," Nestor 2 (2012). Hlm. 1-17.

Hakim, Abdul. "Perbandingan Perekonomian Dari Masa Soekarno Hingga Susilo Bambang Yudhoyono (1945 - 2009)," Ekonomika Bisnis 3 (2012). Hlm. 161180.

Idris, Miftah. "Kerahasiaan Bank Suatu Tinjauan Dalam Aturan Hukum Perbankan Syariah Di Indoesia," $A l$ Amwal 1 (2016). Hlm. 1-29.

Muchsin, "Reformasi Undang-Undang Pemberantasan Tindak Pidana Korupsi Suatu Tinjauan Yuridis," Hukum dan Pembangunan 29 (1999). Hlm. 232-248.

Muhtar, Mohamad Hidayat. "Model Politik Hukum Pemberantasan Korupsi Di Indonesia Dalam Rangka Harmonisasi Lembaga Penegak Hukum," Jambura Law Review 1 (2019). Hlm. 68-93.

Sjahdeini, Sutan Remy. "Rahasia Bank: Berbagai Masalah Di Sekitarnya." Makalah disampaikan pada Diskusi Mengenai Legal Isues Seputar Pengaturan Rahasia Bank Bertempat Di Bank Indonesia, Jakarta,13 Juni 2005.

Tulenan, Vikky. "Pembukaan Rahasia Bank Dalam Tindak Pidana Korupsi," Lex Crimen 5 (2016). Hlm. 93-100

Yanti, Fitri. "Peristiwa G-30-S/PKI Di Balik Penetapan Hari Kesaktian Pancasila Tahun 1965," Historia 2 (2017). Hlm. 33-40.
Yasin, Akhmad. "Keterkaitan Kerahasiaan Bank dan Pajak: Antara Kepentingan Negara dan Pribadi," Konstitusi 16 (2019). Hlm. 212-234.

\section{Internet}

Nagoro, Mukhamad Wisnu. "Menengok Sejarah Perpajakan di Indonesia: Bagian Kedua" https://www.pajak.go.id/artikel/meneng ok-sejarah-perpajakan-di-indonesiabagian-kedua diakses 29 April 2020.

Renata, Alfi. "KPK dan Rahasia Bank" https://www.hukumonline.com/klinik/d etail/ulasan/lt4b0a0278418a9/kpk-danrahasia-bank/ diakses 23 Mei 2020.

\section{Perundang-Undangan}

Indonesia, Majelis Permusyawaratan Rakyat Sementara. Ketetapan Majelis Permusyawaratan Rakyat Sementara tentang pembaharuan kebijakan landasan ekonomi, keuangan, dan pembangunan. TAP MPRS No. XXIII Tahun 1966.

Indonesia, Peraturan Pemerintah Pengganti Undang-Undang Pengusutan, Penuntutan, dan Pemeriksaan Tindak Pidana Korupsi, PERPU No. 24 Tahun 1960, LN No. 72 Tahun 1960, TLN No. 2011.

Indonesia. Peraturan Pemerintah Pengganti Undang-Undang Rahasia Bank, PERPU No. 23 Tahun 1960, LN No. 71 Tahun 1960, TLN No. 2010.

Indonesia. Undang-Undang Komisi Pemberantasan Tindak Pidana Korupsi, UU No. 30 Tahun 2002, LN No. 137 Tahun 2002, TLN No. 4250.

Indonesia. Undang-Undang Otoritas Jasa Keuangan, UU No. 21 Tahun 2011, LN No. 111, TLN No. 5253. 
Terakreditasi Peringkat 4 (No. SK: 36/E/KPT/2019)

Indonesia. Undang-Undang Pemberantasan Tindak Pidana Korupsi, UU No. 3 Tahun 1971, LN No. 19 Tahun 1971, TLN No. 2958.

Indonesia. Undang-Undang Pemberantasan Tindak Pidana Korupsi, UU No. 31 Tahun 1999, LN No. 140 Tahun 1999, TLN No. 387.

Indonesia. Undang-Undang Perubahan Atas Undang-Undang Nomor 7 Tahun 1992 Tentang Perbankan, UU No. 10 Tahun 1998, LN No. 182 Tahun 1998, TLN No. 3790 .

Indonesia. Undang-Undang Pokok-Pokok Perbankan, UU No. 14 Tahun 1967, LN No. 34 Tahun 1967, TLN 2842. 